\title{
New Perspectives on Picture Books
}

\author{
By Lisa Ciecierski* \\ James Nageldinger ${ }^{\dagger}$ \\ William P. Bintz \\ Sara D. Moore
}

\begin{abstract}
The use of picture books has been illuminated as a potential to address important topics such as STEM, fluency, and social justice. Unique genres such as hybrid texts and wordless picture books are also worth considering for instruction. This article explores new perspectives on using picture books. Potentials for using wordless picture books beyond the early grades to support literacy across the curriculum are shared first. Next, we discuss how some picture books lend themselves to the engineering design cycle and can be used as an organizing idea for instruction which focuses on integrating the STEM disciplines. To continue, the prospect of utilizing picture books to strengthen reading fluency while engaging students in rich content area material is discussed. The potentials for using banned and challenged picture books to teach social justice is discussed next. We conclude by presenting practical strategies, picture books to consider for each of the areas, and lessons learned.
\end{abstract}

Keywords: fluency, picture books, social justice, STEM, wordless picture books.

\section{Introduction}

Historically, picture books have been used with young children to enjoy and learn to read. On average, a picture book is 32 pages in length and contains illustrations on every page or every page spread. Picture books appeal to readers of all ages and while they are shorter than a novel, many are highly sophisticated (Ciecierski \& Bintz, 2015). They can help students gain a better understanding of the world around them (Murphy, 2009) and connect to the material being studied in a meaningful way (Taliaferro, 2009; Villano, 2005). Picture books can be utilized to capture students' attention (Routman, 2000) and can also serve as "way-in" books (Keene \& Zimmerman, 1997), providing an unexpected interest into topics that may become interesting to explore (Bintz, 2011). Hence, picture books are short in length but rich in appeal.

Recently, there has been a proliferation of exciting new genres in the professional field of picture books. These genres include but are not limited to: the post-modern picture book highlighting design features such as strategic text placement, varied font sizes and dimensionality of illustrations, non-traditional

\footnotetext{
* Assistant Professor, Language and Literacy, Penn State Erie, The Behrend College, USA.

${ }^{\dagger}$ Assistant Professor, Literacy Education, Elmira College, USA.

$\star$ Professor, Literacy Education, College of Education, Health, and Human Studies, Kent State University, USA.

${ }^{+}$Educational Consultant, USA.
} 
plot structure, all of which invite readers to read complex text in strategic ways. Additionally, hybrid picture books integrate verse and prose, multiple sources of information, mixtures of styles, and multiple functions. These genres offer readers new ways of making meaning. They may also serve as an invitation to educators and readers to consider new perspectives and new potentials for utilizing these types of picture books as well as many other types of picture books for instruction.

The purpose of this article is to inspire readers, teachers, and teacher educators to explore new perspectives and their potentials for making meaning through the transformative nature of the picture book. It is comprised of four sections to represent four different perspectives. We begin by presenting the potential of using Wordless Picture Books and continue by exploring the potential of using picture books to teach Science Technology, Engineering, and Mathematics. Next, we share about utilizing patterned and predictable text in picture books to increase reading fluency while simultaneously promoting content area learning. The fourth perspective demonstrates the potency of using banned and challenged picture books to teach social justice issues. Each section contains a description of the perspective, multiple books highlighting examples of the perspective, and discussion about how utilizing this type of picture book may lend to instruction. We conclude by sharing our final thoughts.

\section{New Perspectives on Wordless Picture Books}

"Wordless picture books prepare students for a solid foundation in reading because they stimulate oral communication and foster literacy"

(Gitelman, 1990, p, 525).

\section{What is a Wordless Picture Book?}

A wordless book is simply a "picture book with no text" (Harris \& Hodges, 1995, p. 282). It can, of course, be read fast and often is by many readers, both young and old. However, it should not be read fast because a wordless picture book is anything but simple. It is a complex, time-honored, literary genre, or art form, that has played a critical role in helping young children develop a positive disposition about books, reading, and learning.

There are a plethora of wordless picture books for readers of all ages. Some of our very favorites are highlighted in Table 1. 
Table 1. Wordless Picture Books

\begin{tabular}{|l|}
\hline Chalk (Thomson, 2010). \\
\hline Float (Miyares, 2015). \\
\hline Flotsam (Wiesner, 2006). \\
\hline Mirror (Baker, 2010). \\
\hline Mysteries of Harris Burdick (Van Allsburg, 1984). \\
\hline One Scary Night (Guillopp, 2004). \\
\hline Return (Becker, 2016). \\
\hline The Arrival (Tan, 2007). \\
\hline The Little Red Fish (Yoo, 2007). \\
\hline The Zoo (Lee, 2007). \\
\hline Trainstop (Lehman, 2008). \\
\hline Unspoken (Cole, 2012). \\
\hline Wave (Lee, 2008). \\
\hline Window (Baker, 1991). \\
\hline Zoom (Banyai, 1998). \\
\hline
\end{tabular}

\section{Using Wordless Picture Books}

Traditionally, parents and teachers have used wordless picture books in a variety of ways and for a multitude of reasons. At home, parents have used these kinds of books for lap reading, and, of course, bedtime reading. These experiences allow parents and children to engage in imaginative, enjoyable, entertaining, and, yes, sometimes surprising, conversations about engaging stories, lovable characters, artful illustrations, and interesting designs, e.g. board books, pop-up books, etc. They also help parents introduce children to the inherent beauty, profound artistry, and immense value of picture books, in general, and wordless picture books, in particular. Most importantly, these kinds of social literary experiences have long-term effects on children. Long term, they pave the way, naturally, smoothly, and effectively, for children to ultimately become life-long members of the literacy club (Smith, 1988).

In school, teachers use wordless picture books to introduce a literary genre or author's craft, namely, visual storytelling, the telling of stories only through visual images. Wordless picture books are excellent to highlight four important notions about readers and texts: 1) readers don't receive meaning from texts, they create it, 2) texts have both surface and deep levels of meaning, 3) surface level meanings are based on what the text says, whereas deep levels of meaning are based on what the text means; the latter requires understanding and interpretation, 4) texts have the potential for multiple interpretations (Ramos \& Ramos, 2011; Sanderson, 2011) and readers need to value the perspectives of others because they enrich their own understandings (Rosenblatt, 1978/1994).

Interestingly, readers of wordless picture books use the same strategies as when reading texts with words (Pantaleo, 2007). They use prior knowledge, make intertextual connections, and consider other perspectives (Crawford \& Hade, 2000). Wordless picture books help readers create meaning through rigorous observation use oral and written language to discuss the story the 
pictures represent (Jalongo, Dragich, Conrard, \& Zhang, 2002). They prompt readers to tell interpret the story in their own words, that is, to personalize the story with an authentic voice (Rosenblatt, 1991).

From a semiotic perspective, typical picture books, those with words and illustrations, invite readers to use both sign systems to crate meaning (Siegel, 1995). Wordless picture books, however, are unique in that they allow readers to use one sign system, the illustrations, to create meaning. Interestingly enough, Berghoff (1993) found that even when text is available, readers use illustrations and drawings to create meaning beyond just the written text. Simply stated, illustrations are critically important for readers to create meaning, whether it is in a typical picture book or a wordless one (Pantaleo, 2007).

Ultimately, the goal of typical picture books and wordless picture books is the same, to help readers become more engaged in and attentive of any text (Sulentic-Dowell, Beal, \& Capraro, 2006). Wordless picture books may be considered as one of the most beautiful art forms in literature and have much potential for sparking new conversations about new perspectives.

Wordless picture books may stimulate interest as well as conversation among readers. Exploring the potentials of award winning picture books to engage and instruct students in the science, technology, engineering, and mathematics may be enjoyable for children may also be used as an invitation to explore and make sense of the world they inhabit.

\section{New Perspectives on Picture Books Related to Science, Technology, Engineering, \& Mathematics (STEM)}

"Scientists investigate that which already is; engineers create that which has never been."

-Albert Einstein

\section{What is STEM?}

The engineering design cycle can be used as an organizing idea for instruction which focuses on integrating the STEM disciplines (see Morgan \& Ansberry, 2015; Lachapelle, Sargianis, \& Cunningham, 2013). STEM is an abbreviation often used for four disciplines: Science, Technology, Engineering, and Mathematics. Science and mathematics are familiar disciplines and we have briefly described engineering above. Technology is subject to the greatest misconception in our modern era. The Standards for Technological Literacy (ITEA, 2000) define technology as, "the innovation, change, or modification of the natural environment in order to satisfy perceived human wants and needs" (p. 242). This reminds us that technology is as much the chair in which we sit as it is the computer on which we type. STEM understanding and STEM thinking is important to us as literate members of society when we make health-care decisions or consider environmental issues when voting. STEM is 
equally important in many of the fastest growing careers.

As STEM becomes more and more prevalent, so do the books that may potentially connected to this concept. Table 2 shares just some of these that may be used in the classroom.

Table 2. Picture Books for STEM

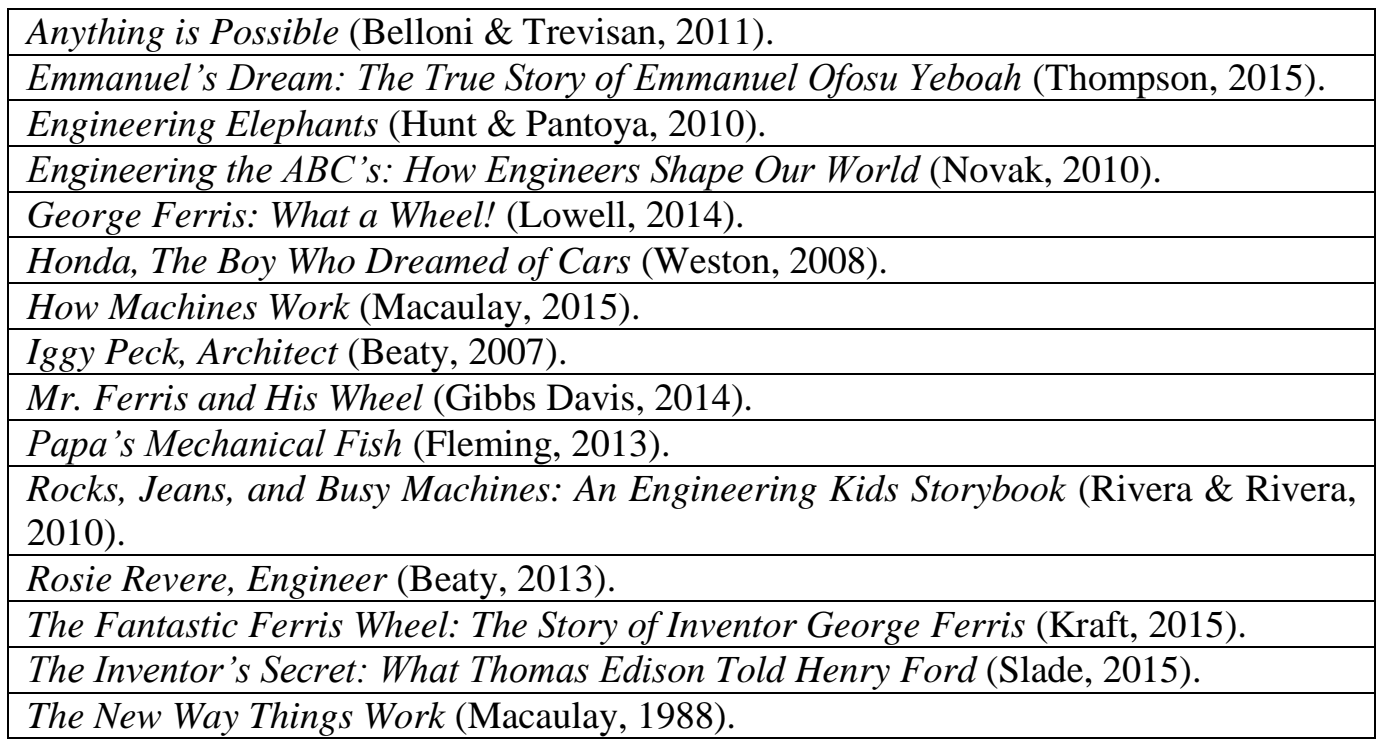

\section{Using Picture Books Related to STEM}

The designed world surrounds us. Our clothing, our homes, the tools we depend on each day are all the result of engineers designing solutions to problems which make our lives better. Our clothes keep us warm; our homes protect us from the elements; our digital tools connect us. High-quality and award-winning literature, particularly picture books, can be used to teach children (and adults) about the engineering design process.

In the picture book, The Most Magnificent Thing (Spires, 2014), the heroine has a vision of a most magnificent thing she will make. Using a wide range of found resources and over the course of many iterations, she brings her vision to life. This story is about the engineering design process, the cycle through which engineers design solutions to problems (Crismond \& Adams, 2012). In this process, engineers work to define and understand the problem, develop possible solutions, build and test models or prototypes, and then reflect and redesign. There typically is no one best solution; rather, engineers work on refining the solution to be the best possible one under the given criteria (what will make this successful) and constraints (what limits of space, money, or other resources are there). Picture books such as The Most Magnificent Thing introduce learners to key STEM ideas and STEM thinking.

From a literacy perspective, these picture books are highly engaging pieces of literature. The fiction/narrative books are excellent examples of the power and potential of realistic fiction. They have engaging story lines, fascinating characters, intriguing settings, and beautiful, if not artistic, illustrations. 
Together, these literary elements create a positive and enjoyable reading experience. The nonfiction/informational books are also excellent reading resources. They include accurate information through carefully crafted text, appropriate text structures (chronological sequence, cause and effect, comparison and contrast, most important to least important, etc.), and attractive illustrations, models, and graphs. Together, these text features make information interesting and understandable for readers.

Other picture books can be used to introduce students to engineering design challenges which other children have solved or to challenges our students might work on. One example is The Boy Who Harnessed the Wind (Kamkwamba \& Mealer, 2012) which tells the story of William Kamkwamba, a young boy in Malawi who dreamed of bringing a windmill to his village. The windmill would provide electricity and could pump water to support the crops during drought so the community does not starve. Much as our heroine in The Most Magnificent Thing, William collects materials from his community and works through many iterations of his windmill until he finds success. This story could be used to introduce the idea of food deserts, areas in urban communities in the US where there is no access to fresh produce. In these areas, there is no land for community gardens and there are no markets bringing fresh produce to the community. What sort of gardening system could students design which would allow residents of this community to grow their own produce within the constraints of their community?

These questions have great potential of stimulating students' thought processes. Utilizing picture books as a foundation to stimulate this way of thinking certainly pertains to STEM. It also relates to using hybrid texts to teach fluency in the content areas.

\section{New Perspectives on Hybrid Texts and Their Use to Teach Fluency across the Content Areas}

\section{What are Hybrid Texts?}

Hybrid picture books integrate verse and prose, multiple sources of information, mixtures of styles, and multiple functions. Characteristic of hybrid text are elements of information in narrative form and a strong illustrative/text relationship.

There are many different types of hybrid texts. We have highlighted books where authors have utilized the hybrid text format to integrate both facts, vocabulary, and even quotes. We have chosen books that utilize the traditional hybrid text format of blending fiction and nonfiction through a story with informational facts as well as books where the author shares poems and highlighting informational facts that connect to these poems in Table 3. 
Table 3. Hybrid Texts for Fluency in the Content Areas

\begin{tabular}{|l|}
\hline A Drop Around the World. (McKinney, 1998). \\
\hline Cucumber Soup (Krudwig, 1998). \\
\hline Dinner at the Panda Palace (Calmenson \& Westoctt, 1995). \\
\hline Flight of the Honey Bee (Huber, 2013). \\
\hline Gotta Go! Gotta Go! (Swope, 2004). \\
\hline Haiku Hike (St. Mary's Catholic School, 2005). \\
\hline One leaf rides the wind. (Mannis, 2002). \\
\hline Out of this world (Skylansky, 2012). \\
\hline Python (Cheng, 2012). \\
\hline Thomas Jefferson Builds a Library (Rosenstock, 2013). \\
\hline Winter bees \& Other Poems of the Cold (Sidman, 2014). \\
\hline The Wright Brothers (Edwards, 2003). \\
\hline
\end{tabular}

\section{Using Hybrid Texts to Teach Fluency across the Content Areas}

Recent introduction of new genres in children's and adolescent's literature have opened up a new and exciting landscape in reading pedagogy with the potential for helping struggling readers increase their reading fluency while accessing grade level content. One of these new genres is called hybrid texts (Maloch \& Bomer, 2013).

This genre offers elementary and middle-grades reading and content area teachers a new way to think about teaching reading, as well as using reading as a tool to teach across the content areas. As a new genre, the power and potential of hybrid text is immense but virtually unexplored. One of the least explored dimensions is the relationship between hybrid text and oral reading fluency. Once thought to be a problem relegated to the lower grades, recent research has show reading fluency to be an issue extending middle and high school as well (Paige, Rasinski, \& Magpuri-Lavell, 2012; Rasinski \& Padak, 2005).

Much research indicates that authentic literature, especially high-quality literature, is an effective tool to teach content area material across the curriculum (Albright, 2002; Bean, 2003; Bintz, 2011; Ciecierski \& Bintz; Murphy, 2009; Palmer \& Stewart, 1997). At the same time there is a body of empirical research that clearly indicates a correlation exists between oral reading fluency and silent reading comprehension (Benjamin \& Schwanenflugel, 2010; Fuchs, Fuchs, Hosp, \& Jenkins, 2001; Rasinski, Rikli, \& Johnston, 2009). Patterned and predictable text has been shown to be an effective way to increase reading fluency (Bridge \& Burton, 1982; Rhodes, 1979). Patterned and predictable hybrid text offers rich content area possibilities for struggling readers while building fluency beyond the early grades. The integration of the patterned and predictable hybrid text elements with narrative information and a strong illustrative/text relationship offer potentials for simultaneous fluency development and content area learning.

These Hands (Mason, 2015) is a powerful book that was used as a foundation to show how hybrid texts may be utilized in the classroom. It begins with Vance. Vance jokes with some of the cast members backstage. In a few 
minutes, he and some of his classmates will be performing a Readers Theatre piece for their sixth grade class. He's nervous but not overly so. Less than a year ago reading aloud in front of people would have been the last thing he wanted to do. The way he plodded word for word through text was as painful for others to listen to as it was for him to undertake. Today, he looks forward to it. Not incidentally, the script the teacher has chosen was adapted from Margaret Mason's hybrid text These Hands (Mason, 2015), a powerful intergenerational story, in which an African American man tells his grandson about a time when, despite all the wonderful things his hands could do, they could not touch bread at the Wonder Bread factory. Based on actual stories of bakery union workers Mason's patterned and predicable text combines the proven connection of oral reading fluency to reading comprehension with the introduction of rich content area material. Young Joseph learns that people joined their hands together to fight discrimination so that one day, their hands-Joseph's hands - could do anything at all in this whole wide world.

The genre of hybrid texts has unlimited potential for use in content area classrooms. As discussed, viewing the use of hybrid texts if various ways may lead educators to considering their use to address the topic of fluency. This extended way of thinking is important to consider in education. Similarly, is the consideration of challenged and banned books to address social justice.

\section{New Perspectives on Picture Books as Challenged and Banned Books}

\section{What are Challenged and Banned Books?}

Challenged or banned books are books that have been questioned for reasons such as violence, offensive language, and containing material that is believed to be sexually explicit. Evans (2015) shares that these books are "demanding, dangerous, and difficult" as well as "fascinating, frightening, frustrating" and even a risk (p. xliiv). She continues to share the emotions that are may be felt in response to these books. They are not books that make us feel warm and fuzzy. It is actually the challenge and the complexity of these books which may appeal to some while challenging others. Consequently, these books might also be perceived as being unsuited for an age group.

Many challenged or banned books are novels. However, considering picture books that are banned has great implications for instruction. Table 4 shares additional texts that may be considered. 
Table 4. Challenged and Banned Books

\begin{tabular}{|l|}
\hline Denver (McKee, 2010). \\
\hline Home and Away (Marsden, 2008). \\
\hline Nappy Hair (Herron, 1997). \\
\hline Rose Blanche. (Gallaz \& Innocenti, 1985). \\
\hline Smoky Night. (Bunting, 1999). \\
\hline The Enemy (Cali, 2009). \\
\hline The Girl in Red (Frisch, 2012). \\
\hline The Red Tree (Tan, 2000). \\
\hline Where the Wild Things Are (Sendak, 1963). \\
\hline Wolves (Gravett, 2006). \\
\hline
\end{tabular}

\section{Using Challenged and Banned Books}

Familiarizing ourselves with the plot of the book as well as the reasons why these books were challenged or banned might engage us in considering interesting points and potential teaching implications. While adults often feel that these books are challenging, it is they, who have problems coping with these types of texts. Young children have to deal with these types of problems on a daily basis in their own life and find benefit to reading these books (Evans, 2015). Three books are presented here by first sharing the plot, sharing the reason why the book was banned or challenged, and then sharing the teaching implications.

Nasreen's Secret School: A True Story from Afghanistan (Winter, 2009) is based on the true story of Nasreen. Nasreen lives in Afghanistan, under Taliban rule, and stopped talking when her parents disappear. Her grandmother enrolls her in a secret school. At the school, Nasreen discovers a world of art, literature, and history, despite the prohibition of learning by the Taliban.

Nasreen's Secret School: A True Story from Afghanistan was challenged because of its religious viewpoint, violence, and a claim that the book is unsuited to the age group. This is interesting for several reasons. First, there are references to children reading the Koran, but there is not any persuasion attempted by the author to encourage the reader to believe in any particular religion. The story line is told from a historical perspective. The violence in the book is inferred. The Taliban comes to the secret school and find girls reading the Koran. This is allowed, so the Taliban leave. Readers' may infer that the consequence to the Taliban finding the girls learning would be violent; however, this is not explicit. Therefore, it would depend on the age and maturity of the reader how this scene is perceived. This may also lead to the appropriateness of the book being shared with readers grades one through four.

Louise Rosenblatt proposes that a readers' interpretation of a text depends on what his or her experiences are (1978/1994). With this thought in mind, it is up to the reader to bring meaning to the text after the author has written it. If the reader does not have the background knowledge to infer the violence that may occur if the Taliban finds out about the secret school, the violence may not be interpreted. Although students' comprehension relies on their background knowledge, this book may be an excellent choice to inspire conversation on 
social justice issues such as the freedom of religion, as well as women's rights and how these rights did and still do differ from culture to culture and country to country.

The second picture book and Tango Makes Three (Richardson \& Parneli, 2005) tells the true story of three penguins who live in the Central Park Zoo located in New York City. Roy and Silo are two male penguins who appear to enjoy each other's companionship. They are often seen swimming and playing together in the water. When the other penguins in the zoo begin hatching eggs, Roy and Silo cuddle and share a nest like the other couples. They even bring an egg-shaped rock back to their nest. A zookeeper who had been watching the penguins decides to give Roy and Silo their own egg to nurture, and the two fathers do a wonderful job doing just that. Their son, Tango, is born and loved just as the other chicks.

This book was challenged because of homosexuality, religious viewpoint, and a claim that the book was unsuited to an age group. There are several interesting points to consider.

First, the book is based off of a true story. Roy, Silo, and Tango are real penguins and so is their story. The book is written for children in preschool through grades three. Again, considering Rosenblatt's transactional reading theory previously discussed would influence the readers' interpretation of this picture book.

While the topic of homosexuality is difficult and sometimes controversial, many children live in a world where homosexuality is part of their life. Children and adolescents around them may not know how to have conversations about this topic and may question what is right and what is wrong. From a social justice perspective, this book might be considered as a "way-in" to this conversation.

Finally Hiroshima No Pika (Maruki, 1980) shares the story of a sevenyear-old girl having breakfast with her family. It seems like an ordinary morning until "it" happens. Told from the mother's perspective, this is the story that brings the bombing of Hiroshima to life. The illustrations and language are graphic to portray this even in a realistic manner. The reader is brought into the story to experience the pain and turmoil of the event.

This book was challenged because it does not represent war as being glorious. It is also challenged for not being appropriate for its intended audience. However, it was not written with the intention of being shared with young children. The suggested audience is grade four and above. While this book is indeed graphic, it shares a perspective of the event that is realistic. War is not glorious, and it is important to recognize and understand historical events so these events do not repeat themselves.

Picture books are not written simply for young children and have great potential for being utilized to enhance the learning and conversations of older students. While many may challenge particular books in the attempt to protect students, considering these books as a "way-in" to difficult but important conversations is worth considering. They may also inspire interest into topics underexplored but important for our future. 


\section{Final Thoughts}

While picture books are often short, they have tremendous potential of being complex and inspiring sophisticated thinking. We have highlighted four perspectives to consider: wordless picture books, picture books related to science, technology, engineering, \& mathematics, hybrid texts to teach fluency across the content areas, and challenged and banned picture books. We hope that these will serve as an invitation to consider other forms of picture books and the many potential they offer to teachers and to students alike.

\section{References}

Albright, L. (2002). Bringing the Ice Maiden to life: Engaging adolescents in learning through picture book read-alouds in the content areas. Journal of Adolescent \& Adult Literacy, 45(5), 418 - 428.

Bean, T. (2003). Using young-adult literature to enhance comprehension in the content areas. Naperville, IL: Learning Point Associates.

Benjamin, R. G., \& Schwanenflugel, P. J. (2010). Text complexity and oral reading prosody in young readers. Reading Research Quarterly, 45(4), 388-404.

Berghoff, B. (1993). Moving toward aesthetic literacy in first grade. In D. Leu \& C. Kinzer (Eds.), Examining central issues in literacy research, theory, and practice (42 ${ }^{\text {nd }}$ Yearbook of the National Reading Conference) (pp. 217-226). Chicago, IL: National Reading Conference.

Bintz, W.P. (2011). "Way-In" books encourage exploration in middle grades classrooms. The Middle School Journal, 42(3), $34-45$.

Bridge, C., \& Burton, B. (1982). Teaching sight vocabulary through patterned language materials. In J. A. Niles \& L.A. Harris (Eds.), New inquires in reading research and instruction (pp. 113-123). Washington, DC: National Reading Conference.

Ciecierski, L. \& Bintz, W.P. (2015). Developing a challenging and integrated curriculum. Middle School Journal 46 (5), 17 - 25.

Crawford, P., \& Hade, D., (2000). Inside the picture, outside the frame: Semiotics and the reading of wordless picture books. Journal of Research in Childhood Education, 15(1), 66-80.

Crismond, D.P., \& Adams, R. S. (2012). The informed design teaching and learning matrix. Journal of Engineering Education, 101(4), 738-797.

Evans, J. (2015). Challenging and controversial picture books: Creative and critical responses to visual texts. New York: Routledge.

Fuchs, L. S., Fuchs, D., Hosp, M. K., \& Jenkins, J. R. (2001). Oral reading fluency as an indicator of reading competence: A theoretical, empirical, and historical analysis. Scientific Studies of Reading, 5(3), 239-256.

Gitelman, H. (1990). Using wordless picture books with disabled readers. The Reading Teacher, 43(7), 525.

Harris, T.L., \& Hodges, R.E. (Eds.) (1995). The literacy dictionary: The vocabulary of reading and writing. Newark, DE: International Reading Association.

ITEA. (2000). Standards for Technological Literacy: Content for the Study of Technology. Reston, Va.: ITEA.

Jalongo, M.R., Dragich, D., Conrard, N.K., \& Zhang, A. (2002). Using wordless picture books to support emergent literacy. Early Childhood Education Journal, 
29(3), 167-177.

Keene, E.O., \& Zimmermann, S. (1997). Mosaic of thought: Teaching comprehension in a reader's workshop. Portsmouth, $\mathrm{NH}$ : Heinemann.

Lachapelle, C.P., Sargianis, K., \&Cunningham, C.M. (2013). Engineer It, Learn It: Science and Engineering Practices in Action, Science and Children, November, 70-76.

Maloch, B., \& Bomer, R. (2013). Teaching about and with Informational Texts: What Does Research Teach Us? Language Arts, 90(6), 441-448.

Morgan, E., \& Ansberry, K. (2015). Every part has a purpose. Science and Children, March, 16-22.

Murphy, P. (2009). Using picture books to engage middle school students. Middle School Journal, 40, 20 - 24.

Paige, D. D., Rasinski, T. V., \& Magpuri-Lavell, T. (2012). Is fluent, expressive reading important for high school readers? Journal of Adolescent \& Adult Literacy, 56(1), 67-76.

Palmer, R.G., \& Stewart, R.A. (1997). Nonfiction trade books in content area instruction: Realities and potential. Journal of Adolescent and Adult Literacy, 40, $630-641$.

Pantaleo, S. (2007). "How could that be?": Reading Banyai's Zoom and Re-Zoom. Language Arts, 84(3), 222-233.

Ramos, A.M., \& Ramos, R. (2011). Ecoliteracy through imagery: A close reading of two wordless picture books. Children's Literature in Education, 42, 325-339.

Rasinski, T., Rikli, A., \& Johnston, S. (2009). Reading fluency: More than automaticity? More than a concern for the primary grades? Literacy Research \& Instruction, 48(4), 350-361.

Rasinski, T., \& Padak, N. D. (2005). Fluency beyond the primary grades: Helping adolescent struggling readers. Voices from the Middle, 13(1), 34-41.

Rhodes, L.K. (1979). Comprehension and predictability: An analysis of beginning reading materials. In J.C. Harste \& R. Carey (Eds.), New Perspectives on Comprehension (pp. 117-129). Bloomington, IN: Indiana University School of Education.

Rosenblatt, L.M. (1978/1994). The reader, the text, the poem: The transactional theory of the literary work. Carbondale, IL: Southern Illinois University Press.

Rosenblatt, L.M. (1991). Literature---S.O.S.! Language Arts, 68, 444-448.

Routman, R. (2000). Conversations. Portsmouth, NH: Heinemann.

Sanderson, R. (2011). Every picture tells a story. English Four to Eleven, 41, 16-17.

Siegel, M. (1995). More than words: The generative power of transmediation for learning. Canadian Journal of Education, 20(4), 455-475.

Smith, F. (1988). Joining the literacy club: Further essays into education. Portsmouth, NH: Heinemann Publishing.

Sulentic-Dowell, M.M., Beal, G.D., \& Capraro, R.M. (2006). How do literacy experiences affect the teaching propensities of elementary pre-service teachers? Reading Psychology, 27, 235-255.

Taliaferro, C. (2009). Using picture books to expand adolescents' imaginings of themselves and others. English Journal, 99(2), 30 - 36.

Villano, T.L. (2005). Should social studies textbooks become history? A look at alternative methods to activate schema in the intermediate classroom. The Reading Teacher, 59, 122 - 130. Doi:10.1598/RT.59.2.2 


\section{Literature Cited}

Baker, J. (1991). Window. New York: Greenwillow Books.

Baker, J. (2010). Mirror. Somerville, MA: Candlewick Press.

Banyai, I. (1998). Zoom. New York: Puffin Books.

Beaty, A. (2013). Rosier revere, engineer. New York, NY: Harry N. Abrams.

Beaty, A. (2007). Iggy peck, architect. New York, NY: Harry N. Abrams.

Becker, A. (2016). Return. Somerville, MA: Candlewick Press.

Belloni, G. (2011). Anything is possible. Berkeley, CA: Owlkids Books.

Bunting, E. (1999). Smoky night. Boston, MA: HMH Books for Young Readers.

Cali, D. (2009). The enemy. New York: Schwartz \& Wade.

Cheng, C. (2012). Python. Somerville, MA: Candlewick Press.

Calmenson, S. \& Westcott, N.B. (1995). Dinner at the Panda Palace. New York:

Harper Collins.

Cole, H. (2012). Unspoken. New York: Scholastic Press.

Edwards, P.D. (2003). The Wright brothers. New York: Disney-Hyperion.

Fleming, C. (2013). Para's mechanical fish. New York, NY: Farrar Straus Giroux.

Frisch, A. (2012). The girl in red. Mankato, MN: Creative Editions.

Gallaz, C. \& Innocenti, R. (1997). Rose Blanche. Mankato, MN: Creative Editions.

Gibbs Davis, K. (2014). Mr. Ferris and his wheel. New York: Houghton Mifflin Harcourt.

Gravett, E. (2006). Wolves. New York: Simon \& Schuster Books for Young Readers.

Guilloppe, A. (2004). One scary night. New York: Casterman.

Herron, C. (1997). Nappy hair. New York: Knopf Books for Young Readers.

Huber, R. (2013). Flight of the honey bee. Somerville, MA: Candlewick Press.

Hunt, E. M., \& Pantoya, M. L. (2010). Engineering elephants. Bloomington, IN:

Author House.

Kamkwamba, W., \& Mealer, B. (2012). The boy who harnessed the wind. New York, NY: Dial Books.

Kraft, B.H. (2015). The fantastic ferris wheel. New York: Henry Holt and Company.

Krudwig, V.L. (1998). Cucumber soup. Golden, CO: Fulcrum Publishing.

Lee, S. (2007). The zoo. La Jolla, CA: Kane Miller Book Company.

Lee, S. (2008). Wave. San Francisco, CA: Chronicle Books.

Lehman, T. (2008). The trainstop. Boston, MA: HMH Books for Young Readers.

Lowell, B. (2014). George Ferris: What a wheel! New York, NY: Grosset \& Dunlap.

Macaulay, D. (2015). How machines work: Zoo break! London, UK: DK.

Macauley, D. (1988). The new way things work. Boston: Houghton Mifflin Company.

Mannis, C.D. (2002). One leaf rides the wind. New York: Puffin Books.

Marsden, J. (2008). Home and away. Melbourne, Australia: Lothian Books.

Maruki, T. (1980). Hiroshima no pika. New York: Lothrop, Lee \& Shepard.

Mason, M.H. (2015) These hands. Boston, MA: HMH for Young Readers.

McKee, D. (2012). Denver. London: Anderson Press.

McKinney, B.S. (1998). A drop around the world. Nevada City, CA: DAWN Publications.

Miyares, D. (2015). Float. New York: Simon \& Schuster Books for Young Readers.

Novak, P. O. (2009). Engineering the abc's: How engineers shape our world. Northville, MI: Ferne Press.

Richardson, J., \& Parnell, P. (2005). And Tango makes three. New York: Simon \& SchusterBooks for Young Readers.

Rivera, A., \& Rivera, R. (2010). Rocks, jeans, and busy machines: An engineering kid's storybook. San Antonio, TX: Rivera Engineering. 
Rosenstock, B. (2013). Thomas Jefferson builds a library. Honesdale, PA: Calkins Creek.

Sendak, M. (1963). Where the wild things are. New York: Harper and Row.

Sidman, J. (2012). Winter bees \& other poems of the cold. New York: Houghton Mifflin Harcourt Publishing.

Skylansky, A.E. (2012). Out of this world: Poems and facts about space. New York: Knopf.

Slade, S. (2015). The inventor's secret. Watertown, MA: Charlesbridge.

Spires, A. (2014). The most magnificent thing. Toronto, ON: Kids Can Press.

St. Mary's Catholic School (2005). Haiku hike. New York: Scholastic.

Swope, S. (2004). Gotta go! Gotta go! Melbourne, FL: Sunburst Book.

Tan, S. (2000). The red tree. Melbourne, Australia: Lothian Books.

Tan, S. (2007). The arrival. New York: Arthur A. Levine Books.

Thompson, B. (2010). Chalk. Indianapolis, IN: Young Hoosier Book Award.

Thompson, L.A. (2015). Emmanuel's dream: The true story of Emmanuel Ofosu Yeboah. New York: Schwartz \& Wade Books.

VanAllsburg, C. (1984). The mysteries of Harris Burdick. Boston, MA: Houghton Mifflin Harcourt.

Weston, M. (2008). Honda: The boy who dreamed of cars. New York: Lee \& Low Books.

Wiesner, D. (2006). Flotsam. New York: Clarion Books.

Winter, J. (2009). Nasreen's secret school. La Jolla, CA: Beach Lane Books.

Yoo, T. (2007), the little red fish. New York: Dial Books for Young Readers. 